\section{【有機溶 郕】}

201

卧内ベンゼン投与したウサギの末梢血所見

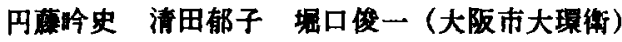
黑田素一（大阪市罢科研）

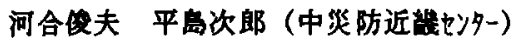

〔はじめに〕 in vitroでのベンゼンとS9mixを加 えた培盖梱绹や、in vivoでの動物にベンゼンと 5bromodeoxyuridine (BrdU)を注入した情湅湅胞で 姉妹染色分体交频度（SCE）加增加するとの 報告がある。一方ベンゼン嫘露者の血液を培羡し た方法(in vivo-in vitro)で著しくS C E 加增加 したとの報告はない。そこでウサギにべンゼンを 投与して柽時的に血中ベンゼン浱度、白血稢数、 白血球像および末梢血を培暴してのS C Eの変化 を調へた。

〔方法〕 ベンゼン250mg/体重kgにTueen80を加え た生食分敉液をウサギ（日本白色種メス12匹、38

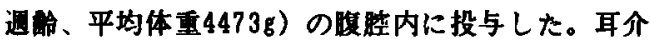
解脈より释時的にへバリン採血した武料について 以下の検查を行った。血中心゙ンゼン：気液平衙 · ガスクロマトグラフ法。白血球数：計算板法。白 血球像：塗抹メイギムザ染色で模鏡。SCE：全

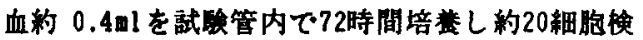
鏡した。（第58回産街椌演集p.21参照）

〔結果】ウサギ12匹のうち9匹は96時間以内に死 亡した。血中べンゼン浱度は投与1時間後には、す でに最高湜度 $(7 \mu \mathrm{g} / \mathrm{ml})$ に達しており、その後半源 期䄪4時間で減衰し、48時間後にはほほ消失した。 白血球数は投与前加平均 $10700 / \mathrm{mm}^{3}$ 標策偏差5200

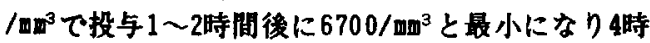
间啳には回復がみら九た。白血球を成好酸球、好 酸、好塩基球、单球、リンパ球に分類してみる とヒトでの好中球に相当する偽好酸球は投与前が 4100/m゙であったものが投与4時間啳から增加しは しめ、8時间挠に10700/am 娍少し96時間後には1800/m的になった。リンパ球 は投与前が6200/m地で投与1時間後にすでに娍少が みられ、2時間後には2200/ $\mathrm{mm}^{3} に な り 24$ 時間後には 回復がみられた。好酸球、好塩基球、単球はそれ ぞれ白血球全体の1\%前後であるため释時的卒化は つかめなかった。その他異常䎩胞は認めなかった。

S C E は投与前が平均7.23/ce11、整染伲差1.51

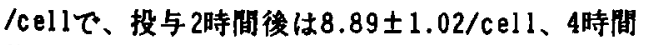

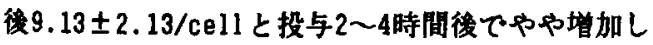
ているようにもみえるが、䀧露前に比へて有意な 差は認めなかった。
202

有機溶凨と顀血

小川隶恭、後藤稠(阪大医環境医学)

鎌田すま子、平松紘一（関労健診センター）

有機溶剂健診（特にシンナーー、トルエン類） において買血検査がどの様な意味を持うのかを 知る目的で健診デー夕を検討したところ、トル エン類䀧露者群に赤血球が大球性高色素性傾向 を示す群の出現を示唆する結果が得られたこと を昨年秋の有機溶剤研究会に於て発表したか、 今回は更に新しいデー夕を加えて蚞討すると共 に群分類の客観化を試みてみた。大型管を製造 しているA（トルエン類）、B（ステレン）二 工場と鋼板の全装を行っているC工場（トル工 之類）ての三回の有機溶郕煡診䇾診者を対象と した。全員男性である。年齢に関してはA、B、 Cの㮌で平均年龄加若くなっている。A工埸の 代表的な作業場の環境浱度活平均て約 $30 \mathrm{pum}$ と報告されている。C工埸て流最大测定点 20 $\mathrm{ppm}$ 、平均 $5 \mathrm{ppm}$ 以下である。しかしスボッ卜

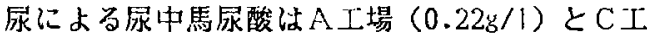
場 $(0.22 \mathrm{~g} / 1)$ では差がなかった。各回筫血娭査 として赤血球数、血色素量、ヘマトクリット值 そして平均赤血球容積、平均赤血球血色素量加 算出されているのてそのデータを用い、赤盘球 数、血色素量を変数とした二次元平面分布図を 作成し分布の山の形を娭討した。何れも主ビー クと赤血球数、血色素量が少ない所に副ビーク もしくは滆壮の二峰を認めることが出来た。こ の副ピークは年秢と共に出現し、主ピークは加 路による移動败殆どなかった。更にA工場では 副ピークに接して血色素量の多い方向に小さな 山(特巽群)を識別出来た。C工場で纱血色素 量の多い方向への山の広がりは認めるが対応す るビークは認められなかった。B工場では览色 素箸の多い方向への山の広がりが一番少なかっ た。次にA工場対象者をそ心分布加污群に分 けた。各群での瞕種の集筫性は認められならつ た。特異群では MC H が高いのは群の設定から 自明であるが更にMC V が有意に高いことが分 かった。以上の群分けを客観化する目的でクラ スター分析を用いた。分類上MC Vが重要な因 子となっていることが分かったので 3 工場に関 してそれぞれ赤血球数、血色素量、MCVO 3 因子に関してウオード法で分析した。そうする とC工場においても赤血球数、血色素量は正常

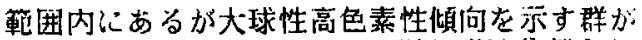
分離できた。B工場ではその样な群は分離され なかった。A、C二工場におけるこの樣な特異 群の出現はトルエン類の慢性的低惯度暸簬が造 血機能を抑制する可能性を示唆している。 
203

労衝者にみられたベンゼン・トルエン間の代謝抑 制

中塚晴夫·井上修·清治和則 - 笠原美幸 渡辺孝男 ·池田正之 (東北大医衛生)

ベンゼン $(\mathrm{B})$ トルエン $(\mathrm{T})$ の混合曝露時に、単体曝露 に比べ如何に代謝が修飾されるかを知るためB群 65名、T群35名、湝合曝露群 (M) 55名、対照群 (C) 35名 の女子工員の曝露濃度をがスバッジ法で测定し，Bの

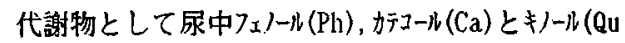
)、Tの代謝物として馬尿西 (Ha) とo-クレ゙ール 測定した. 测定値はCreatinine (Cr) 濃度と比重 (1 .016)で補正、B、M群ではB曝露濃度と $\mathrm{Ph}, \mathrm{Ca}$ とQu 各々との 1 次回帰式と相関係数を、TとM群ではT 曝露濃度とHaあるいは。Cとの 1 次回帰式と相関係 数 (R)を求め, M群では尿中代謝物浀度を目的变数， B · T港度を説明変数とする重回帰分析も行った。

尿中代謝物濃度主曝露濃度と有意な正相関があ り，混合曝露の勾配は単独曝露に比バて小さく共 存物筫の代謝相互抑制が示された。また，TのB 代謝阻害の程度 $(4.1 \rightarrow 1.81)$ の方が BのT代謝抑制 の程度 $(10.77 \rightarrow 8.46)$ より顕著であった。

$\mathrm{B}$ 群 $\mathrm{Ph}=4.10 \mathrm{~B}+15.6: \mathrm{R}=0.858$ 記号は本文

$\mathrm{M}$ 群 $\mathrm{Ph}=1.81 \mathrm{~B}+14.7: \mathrm{R}=0.760$ 中の定義に

$\mathrm{T}$ 群 $\mathrm{Ha}=10.77 \mathrm{~T}+159.8: \mathrm{R}=0.827$ 同じ

M群 $\mathrm{Ha}=8.46 \mathrm{~T}+129.3: \mathrm{R}=0.700$

M群の重回帰分析の結果でも Bの代謝物と B 曝 露濃度は正の相関， $\mathrm{B}$ 代謝物濃度と $\mathrm{T}$ 曝露濃度間 ではPh，Quで相関は負，Caでは零に近い值であった。 T代謝物に対する $\mathrm{T}$ 曝露濃度の相関係数はHaと oC いづれも正，B曝露濃度とでは負であった。

$\begin{array}{lllc} & \text { 重相関係数 } & \text { Bへの相関 } & \text { T八の相関 } \\ \mathrm{Ph} & 0.804 & 0.793 & -0.163 \\ \mathrm{Ca} & 0.711 & 0.704 & 0.073 \\ \mathrm{Qu} & 0.745 & 0.717 & -0.229 \\ \mathrm{Ha} & 0.777 & -0.094 & 0.775 \\ \mathrm{oC} & 0.667 & -0.032 & 0.667 \\ & \text { Cre補正值での相関 } & \end{array}$

以上よりベンゼン・トル忹は相互にその代謝を抑制 し，その㑯向はベンゼンの忚代謝抑制よりトルンのの ベンドン代愔㧕制の方が影著であることが明らかと なった
座長のまとめ（201～203）

$$
\text { 池田 正之（東北大衛生） }
$$

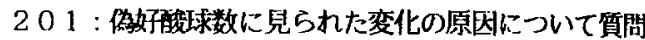
および追加発言があり、恐らくベンゼンに特異的ではな く、非特異的な炎症あるいはストレスに関連した現象と 思わ扔る台の回答があった。またS C E等の所見が除性 てあった点について投与条件・投与量について更に检討 したい旨の追加説明があった。

202 : 発表で言及された「まピークと副ピークもしく は票扰の峰」の読みとり方について例えば、A工場45 才〜55才群の場合、図中央の 3 ・5の集積が主ピーク その左下の $4 \cdot 1 \cdot 40$ 集皘か副ピ一クを示す旨の追加 説明があった。

$203: \mathrm{B} \rightarrow \mathrm{P} \mathrm{H} \cdot \mathrm{CA} \cdot \mathrm{QU}$ ○代謝経路、混合群での B対厂の比、代謝抑制であることの証批およひ屎中代謝 物洘度の補正法について質問があり、B $\rightarrow \rightarrow \mathrm{PH} \rightarrow \mathrm{QU}$ と $\mathrm{B} \rightarrow \rightarrow \mathrm{C} A$ の経路を想定する考え方が有力であるこ と、B対 $\mathrm{T}$ 比が一定でないために重回帰分析を行った こと、労陲者の調查は横断調查であるが、他に動物実揱 の成蹟があり、その成綪との対応で代謝抑制と結論しう ること、補正については特定の補正法にさだからず、非 補正、となる、クレアチニン補正、比重補正の結果を列 挙した旨の四答があった。 
204

牮hanolとBenzene の代橉に関する相互作

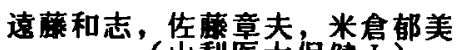

$$
\begin{aligned}
& \text { 中島民江（山梨医太保健 I) }
\end{aligned}
$$

【はじめに】私達は毎日一定量のEthanol を投与しているラットにBenzeneを繰り返 し暴富するとEthanol の血中湍度がしだい

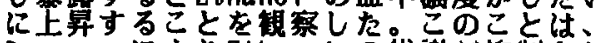
Benzeneにより Ethanol の代搠が抑制され ることを示唆している。また、このような 現象は他のToluene やTrichrolo ethylene などの物買では钼察されなかった。本泰駼 ては、このBenzeneによるEthanoiの代謝 抑制の磁棈について娭討を行なった。

【結果・考察】Wistar系雄性ラットにお

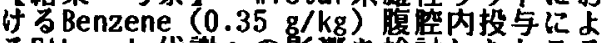

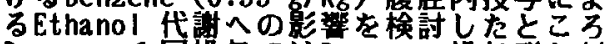
Benzene 1 回投与ではBenzene 投与壁と対 照群の間に差はなく、Benzene 4日間連続 投慗により Ethanol 代謝の抑制が有意な差 として認められた。

Ethanolの代即の律速段階は、NADHO再酸 北てあると考えられている。そ己て、NADH の主な再致化の場でるミトコンドリアに おけるBenzene の影路を検討した。りンコ 酸シャトル系の基筧を䭂和させた条件で、 Benzene 投与群およひ対照群のミトコシド リア呼吸活性を比较したが有意な差は認め られなかつた。しかし、呼吸度系にBenzene投与時の最高血中岶度であるBenzene( $4 \mathrm{mM})$ 共存時には、State 3 か $40-50 \%$ 抑制 された。また、この際State 4 にはほとん ぼ影整がられなかった。また、它の阻害 數度においてむBenzene 投与群一対照群間 に差は認められなかった。

NAOH脱水羡酥素活性住Benzene (4 mM) 共 存ても阻害されず、Benzene 投与群一対照 群間に差はなかった。

肝可涴性画分のAlcohol dehydrogenase , Malate dehydrogenase, Glutamateoxal oacetate transam inase 活性测定 たところAlcohol dehydrogenase 活性にお 心市有意差かみとめられ、Benzene 投与群 の活性䋃、対照群の54\%に娍少していた。 ま字、Benzene は、Ethanol に対して非競 その的にAlcohol dehydrogenase 阻害し結果

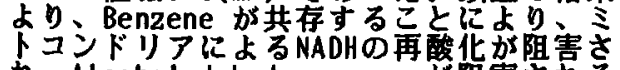
h.Alcohol dehydrogenase 加阻害され ことか明らかとなった。さらにBenzene 投

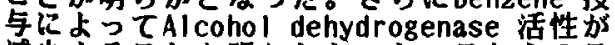
減少することむ明かとなった。れらのこ とがEthanol の代詂抑制に結びついている と考えられる。

Ethanol はAlcohol dehydrogenase 経路の みならずMicrosormal ethanol oxidizing systemによっても代非される。この系む含 めたEthanol 代期に対するBenzene の影觢 の模討は今後の讄としたい。
205

\section{トルエン代謝における人種差}

清治和則，井上修，(東北労災健診センター) 中塚晴夫，笠原美幸、渡辺孝男，池田正之

(東北大医衛生)

体内に摃取されたトルエンは代謝を受け，主に馬尿 酸や。ークレゾールとして尿中に排泄されるが，尿中 に排泄された馬尿酸、0-クレゾールの值及び。-ク レゾール／馬尿酸比と気中トルエン温度との関係を 調べた結果，トルエン代謝には日本人，中国人，卜 ルコ人の間で人種差が存在することを明らかにした 調查対象は日本人 (男: 74名, 女 : 56名)，中 国人（男：75名，女：117名），トルコ人（男 : 17 名)で個々の人種により得られた午後尿を模 体として，馬尿酸， ○ークレゾールを测定し，馬尿酸 はHPLC法（緒方等：1977年ににより，0－ク レゾールはF 1 D - GC法 (長谷川等：1983年) で測定した.クレアチニンは比色法（池田等：19 69 年〉，比重は屈折型尿比重計を用いて測定した。 呼気帯中のトルエン浠度は拡散型個人サンプラーを 作業荓始から終了時まで装着し测定した（池田等： 1984 年). 日本人のデー夕は長谷川等 (198 3年）の報告を引用した（但し分析は同じ研究室で 同じ機器を用いて行った〉。

(䊅果と考察) 調㚗対象の多い日本人と中国人につ いて気中トルエン曝露濃度一尿中代勆物濃度との间 の相関関係を解析したところ，両群とも男女ともに 尿中馬尿酸， 0 -クレソール湛度はトルエン瀑度の增 加にともなって直線的に上昇したが，回帰直線の勾 配は日本人と中国人の間で顕著な差があり，男子中 国人の場合，馬尿酸排泄量は男子日本人の构半量， 女子では䄪2／3しか非泄されなかった．－クレソ 一ルについては差がみられなかつた，さらに男子ト ルコ人，男子日本人，男子中国人のデ一夕より，よ

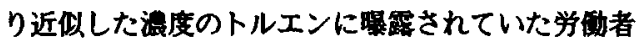
を選択し、0ークレソール/馬尿酸比を 3 群间で比較 したところ日本人 ( $\mathrm{M} \pm \mathrm{S} \mathrm{D} ; 0.48 \pm 0.14)$

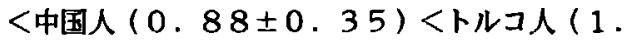
$93 \pm 1.71$ ) の順を示し,トルエン代謝には人

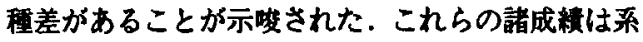

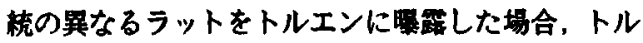

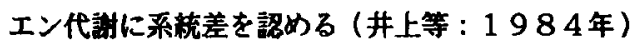
ことと良く対応している.（0-クレソール／馬尿酸比 は $10^{3}$ 倍した.） 
湿合溶䬉の経皮吸収について（1） トルエンの経皮吸収に及ほす溶媒の影慗

\section{鶴田 䙾（産医研）}

[目的］溶剤類は単体として0子ならず、混合 系としても多量に使用されており、シンナーなど はトルエンを主成分とする典型的な混合溶剂の一 腫であ。しわしにのような混合溶剂での各々 の容輸の経皮吸収に関する知見はほとんどない。 そこて、トルエンの経皮吸収に改ぼす溶媒の影䋨 を明らかにするために、種々の溶媒を用いて $50 \%$ トルエン混合溶剂を作り、これらの混合溶剂での トルエンの経皮吸収量をマウスを用いて定量し、 トルエン単独の場含との比較検討をした。

[方法]溶媒にはバンゼン、酶酸エチルおよび メタノールの云種を選ひ、それぞれの溶媒を用い て50\%トルエン混合溶戍を調製した。これらの混 合溶剂でのトルエンの経皮吸収量は前回に報告し たマウスを使用する経皮吸収測定法によった。即

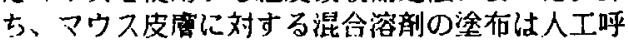
吸器を接続した麻酔マウスの脱毛腹部皮耍に面糟 3.14c mのガラスリングを接着固䇥し、そのな かに試料溶剂 $0.5 \mathrm{ml}$ 1を加えて密封し行った。一

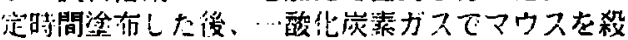
し、ガラスリング内の溶剤を除去してから塗布部 皮瞥をガラスリングごと切除したマウス在直ちに 液体窒素中で凍結した。卜ルエンの経皮吸収量 は混合溶剂を塗布したマウスでのトルエンの呼気 排泄量、体内残存量および代謝量の総和で示され るので各々の量を求めた。体内残存望は泎体眰素 中で作ったマウスの全身凍結粉末組織の一定量に 二酸化崖素を加えてトルエンの抽出を行い、ガス クロで分析定量した。呼気排泄量と代謝量は体内 残存量加算出した。

[結果］種々の溶蝶でのトルエンの経皮吸収曲 線は初期にlag phaseがあり、次いで定常状態と なる二相性を示し、トルエン単独の場合と同様て あったが、経皮吸收速度は溶媒により非常に暴な る事が示された。メ夕ノール溶媒の場合ではトル エン単独に比べて初期、定常状熊共に約 5 俉もの 増加を示した。酢酸工チル溶媒の場合妒卜ルエン 単独の場合と同じか僅かに低下傾向を示し、ベン ゼン溶媒の場合仕1/3-1/2程度の低下を元した。

このような溶媒の効果加希釈染とどのような関係 になるかは今後娭討する予定である。

[結論] 混合溶郕での各々の溶剂の経皮吸収は 混合系の成分によって非常に变化することが示さ れた。特に、トルエンの経皮吸収に及ばすメ夕ノ ールの作用からメタノールを含有するシンナーを 使用する場合にはトルエンの経皮吸収に十分注意 する必要がある。

\section{佐藤光男（産医研）}

204:エ夕ノール代媩に及ほすべンゼンの影讋を 見た一連の研究である。エタノール代韵に及ほ すベンゼンの影䙳は、ベンゼンの非特晴的な作 用と考えてよいか、の管間に対しState 3 が抑 制され、State 4 にはほとんど影帮がみられな いか、クロロホルムではこの逆の現象を示し、 State 4 が影辢を受ける。エ夕ノールは钦食に より多量体内に入るか、有检溶剂の体内侵入量 は少ないのて、実際にはこの漛なことはない。 しかし此の実㻌は、労働者がアルコールを炊ま なくなるという現㙅の事実加ら何故この漛なこ とか起こるか、ということから始めたもので る、という意图か説明された。エタノール摄取

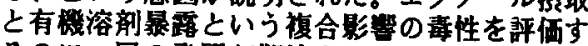
るのに一層の発展が期待される。

205:トルエンに暴篷したとき尿中馬尿酸の排㴖 量について日本人と中国人と比较したもので る。食事、生活様式などの理境因子が巽なる日 本人と中国人て、中国人の尿中馬尿酸排湛量か 少ないこと、またトルエンが代䜊されて馬尿酸 に行くか又はクレゾールに行くかは何に起因す るか、に対して抱合に用いるグリシンブールの 差、アルコール摄取による琴算の差などが考え られるとのことてあった。この演題は生物学的 モニタリング、BEI 值を决める場合大事な䦓嗄 であると思う。

206:有稢溶剂の経皮吸収に閏する一連の研究で 今回は混合溶剂についての報告である。トルエ ンにメタノールを混合するとトルエンの経皮财 収量かトルエン単独より增えるが、トルエンの 吸収はこの混合比率に侤存するかどうか、の角 問に対して、この点に関しヒトてのデータては MEK，MBK の系では、MBK てみると同じといわれ ていること、この㸚皮吸収には皮㢆中の水分量 が問題であり、例えばキシレンとインブタノー ルの $50 \%$ 湿合溶刺では単独に较へキシレンの吸 収は低下するが、イソブタノールを水能和させ た啳キシレンと湿合させて用いると，キシレン 単独と同し财収量を示し、皮虚中の水の作用か 関連する様であること、またメ夕ノールの界面 活珄效果が考えられないか、に対しメタノール の比苹を75\% と変えると投収が変わってくるの て、浸透压，蒸気圧が変わると考えられるのて 此等の因子により变わると予洒しているが，さ らに梄性同志、桠性と非檑性溶媒など色々組合 せて今後さらに検討したいとの事であり、結果 か期待される。 
安定同位体トレーサー法を用いた有機容郕暴露評価 (II)

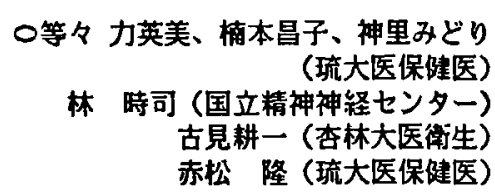

作業環境中の有機溶郕に対する労㑬者の暴路の実

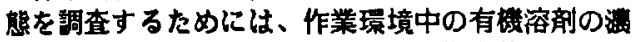
度の推定は覀めて重要である。生物学的モニタリ

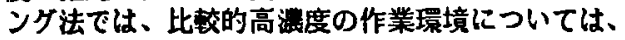
作業学俔者中の溶郕由来の代誰産物の定量から、あ る程度の推定が可能である。しかし、有機容剂谴 度の低い作業条件下では、トルエンなどのように、 生体由来と有㯕溶郕由来の代謝産物が一致する場合 には、作業環境瀑度を推定することは团難である。

また、長期に渡る低瀑度暴焉を受计た作業者の場 合、作業者の生体内代㽎汃、韭暴露作業者と比较し て、どの样な相连があるか、未だ明確ではないよう に思われる。以上の镍点から、本研究蛙、慢性的 有機溶郕暴露評価のための基喏的梌討の一㻴として 負イオン化学イオン筫量分析法(NICIMS)で、トルエ ン・馬尿酸の代謝系の生体内動態を明らかにするた めに、ラットにトルエン負荷を比较的長期間投与を 施行したあと、安定同位体標撞トルエンを負荷し、 NICIMS法を用いて分析を行った。

トルエンーd0を0.1mmol/m1 オリーブ油溶液とし 体重270-290kgのWistar系雄性ラット各々1 O匹に、 $0.1 \mathrm{mmol} / \mathrm{kg}$ 䧗腔内注射を行った。ラット群に2 カ月間連统投与した後、実駼に供した。これとは別 に、コントロール群に、オリーブ油を 2 力月間連続 的に投与した。トルエンーd02力月投与後の、

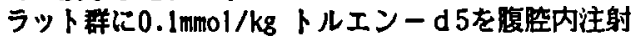
し、 $30 \sim 60$ 分間の蓄尿を 24 時間施行した。 希积尿に内部標準のH A - d 2 メチルアルコール溶 液 (200ng) を加えた後、水で国とした。 $\mathrm{NaCl} 、 2$ NHCIを加え、酷酸エチルを加えた後、振とうした。 酷酸エチル居はNa2S04 て蒸発䡎燥後、その一部 を前处理用H P L Cに供した。

トルエン暴蕗群のトルエン由来のH Aの最大筷度 への到達時間は、今回の実駼の䡉囲内では、コント ロール群と比較して羊延したのに対して、内因性の HA では、戞延は見いだされなかった。また、トル エン由来のH Aの代謝量は、コントロール群におい て增加した。一方、骁報の結果から、トルエンの 短期投与（2 週間）の代䚹変化では、HAの最大瀑 度への到達時問は、暴㯝群の方が短くなっているこ とから、トルエンの投与期間の相遣による、トルエ ン・馬尿酸代㴬系の变化が予想される。

\section{トリクロロエチレンによる肝楽物代謝酥素の変化 - -Epoxide hydrase- -}

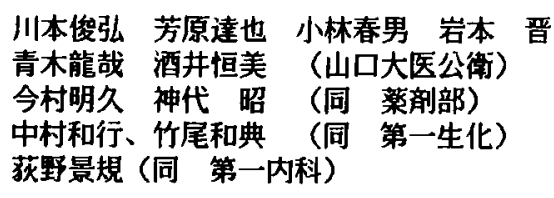

チトクロームPー450は種々の萝物を酸化し、 エボキサイド環を形成するが、このエボキサイド 環は、Epoxide hydrase (以下E Hと略す) により 酻素的に水解され、trans-dihydrodiol を生成す る。トリクロロエチレン（Tr i ）もまた、ミク ロゾームのチトクロームPー450にて monooxygenation をうけ、トリクロロエチレンオキサ イドを形成することはよく知られており、T r i 代謝におけるE Hの関与が疑える。しかし、T r i とE Hとの相互関係についての報告はいままで にほとんどなされていない。そこで今回演者らは、 T r i の投与により肝のE Hの局在に变化がある かどうかについて、免度組緒化学的に検討した。 また、フェノバルビタール（P B ）、3ーメチル コラントレン（MC）の及ぼす影警についても同 様に比较検討した。

体重 $220 \mathrm{~g}$ 前後のウィスター系雄ラットを実駼 钦物としてもちいた。ラットを4群に分け、P B $80 \mathrm{mg} / \mathrm{kg}$ in serineを 4 日間、 $\mathrm{MC} 20 \mathrm{mg} / \mathrm{kg}$ in olive oil を 4 日間、 $\mathrm{T} \mathrm{r} \mathrm{i} 1.0 \mathrm{~g} / \mathrm{Kg}$ in olive ○ilを5日間、それぞれの群に腹院内投与した。 また、コントロール群は olive oil あるいは生食 を同粎に投与した。最終投与後䋓食とし、24時間 後に䉼頭を行い、肝組瀻を採取し、10\% 中性ホル マリンにて固定した。抗E H血清は、ラット E H をFreund's complete adjuvant と混合し、ラビッ 卜を免疫して作製した。今回用いた抗 $E \mathrm{H}$ 血清は、 Gann 73:349-353，1982にて報告した血清と同じ血 清をもちいた。

E Hは、P B , MC，Tri iよびユントロー ルのいずれの肝実筫細胞にも認められた。コント ロールラットの肝では、 centrilobular region $の$ 肝細胞が midzonal および peripheral region の 肝細胞より強く染まっていた。P B投与群では、 centrilobular regionの染色性は強くなり、midzonal region までEHによる染まりが広がってい た。MC投与群はコントロール群とほほ同様の傾 向を示した。T r i 投与群ではコントロールと同 様に centrilobular region の肝辎胞が midzonal,peripheral region の肝細胞よりよく染ま っていた。さらに、midzonal から peripheral region にかけて、数個の肝細胞が散在性に強く染 まっていた。 
Trichloroethyleneおよびその代揧産物のラット肝 microsome醉素に及ぼす急性影望

今村明久、神代 昭（山口大医薬剂部）、芳原達 也、川本俊弘、小林春男、岩本 晋、酒井恒美 ( 同公衛）、中村和行、竹尾和典（同第一生化学）

[目的］トリクロロエチレンとその代謝産物（ク ロラール、トリクロロエタノール、トリクロロ酢 酸）が、それぞれの代謝過程でラット肝ミクロソ

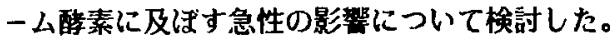

[実験方法] ウィスター系雄性ラットを用い、 一群を 5 匹ずつとし、薬剤投与後 $1 、 2 、 3$ 時間 目に肝瀻を摘出した。トリクロロエチレン（T R 1）は流動パラフィンで 6.7\%溶液とし、抱水ク ロラール (CH) とトリクロロエタノール（TC E）は生理食塩液に、トリクロロ酿酸（T C A） は水酸化ナトリウムで中和して生理食塩液に溶解 し、いずれも5\%溶とした。投与量は、T R I 200mg/Kgとし、C H，TCE，T CAはいずれむ $100 \mathrm{mg} / \mathrm{kg}$ とした。投与方法は、腹想内投与とし、 投与前 24 時間は䋓食させた。対照群にはそれぞ れの希积に用いた溶液を投与した。肝ミクロソー ムの分離は、T.A.Van Der Hoeven らの方法で行 つた。チトクロームP - 450 (P-450) と チトクロームb 5 （b 5) の定量は、T.Omura と R.Sa to の方法で行い、NAD P H ーチトクロー

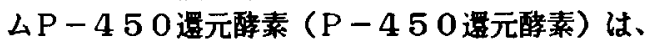
H.W.Strobel らの方法て活性を测定した。蛋白 度は、0.H.Lowry らの方法で決定した。[結果と 考察] P-450の比活性については、全ての実 験を通して、T R I 投与群の 1、2、3時間目と、 C H投与群の $1 、 3$ 時間目に、有意な低下が見ら れ、T C Eと T C A投与群では差は見られなかっ た。b 5，P-450遣元醇素の值については、 いずれの投与群にむ、有意の差は見られなかった。 T R I は、TR I epoxideに代碀され、これが醇 素の関与なしに更にC Hに代謝されることが示峻 されている。TR I epoxide冲、Heme蛋白に結合 し、この蛋白の崩俵をひきおこすと考えられてお り、今回の結果は、その可能性を強く示唆してい る。また、CHについては、経口投与後、初回通 過効果をうけ、ほとんどがT C Eと T C Aに代謝 され、この代謝は肝稢で行われることが知られて いる。P-450の比活性の低下は、C Hが、こ の代謝過程で、P-450を消䩀あるいは破軖す るものと思われるが、その機序については不明で ある。

\section{传藤 章夫（山梨医大Ｉ保健）}

207 ：昨年に引き続き安定同位体トレーサ 一法によるトルエン投与ラットにおける馬尿 酸の排せつ経過を钼察した。今回の実駼は $0.1 \mathrm{mmol} / \mathrm{kg}$ という極く微量のトルエン投与 で外因性（トルエン由来）馬尿酸の排せつ経 過を追跡できたことに意義がある。現在、吸 入動物実駼を実施中ということであるが、基 硞的研究を重ねたのち、同法によるヒトでの トルエンー馬尿酸の仕事が期待される。

208 : トリクロロエチレン代謝の第一段階 がエチレン結合のepoxydation であることに 着目して、トリクロロエチレンのepoxide hydrase（EH）に対する影䈏を免疫組㙨学的に 検討しようとしたものである。ラット所から 精製したウサギ抗EH血清を用いて、肝EHの小 葉内局在を钼察することに成功した。トリク ロロエチレン投与ラットではフェノバルビタ ールあるいは3-メチルコラントレン处理ラッ トとはEHの局在性が異るという。

209 : ラットにトリクロロエチレンを与え ると 1 時間後に肝ミクロソームのcytochrome P-450 合有量が一時的に低下するという実秷 結果が示された。これに対して中島（信大・ 医・衛生）から、1 時間值のミクロソーム蛋 白量加增大しているために単位ミクロソーム 蛋白当りで表現されるcytochrome P-450が計 算上低下したのではないかとう筫問があっ た。演者らはミクロソームの調繁に当って肝 灌流を行っている。この探作が测定值に影䍃 を与える可能性む否定できないので追武を期 待したい。 
混合有機溶剂蒸気の組成変化の予娜について 左右田礼典 (産医研)

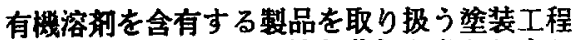
などの作莱環気中には、溶剂蒸気が多かれ少な 加存在する。単一成分の溶剂方使用される場 合恃少なく、混合溶剂として使用される場合が 多い。この際発生する蒸気も混合成分てあり、 かつその蒸気の成分比が時間と共に变化するこ 之が多い。溶剂の蒸発に伴う蒸気成分比の変化 を予测することは、環境测定や環境管理の面に おいて必要なことである。例えば、環境測定に よく利用されるガス検知管は、化学的性馆の似 た他の成分の干涉を受けるが、その程度は成分 此が異なれば变わるから、何らかの方法で共存 成分の割合の変化を予测できれば便利である。 湿合溶剂が理想溶液でちれば、各成分の蒸気圧 (分圧) は溶液中における各成分のモル分率と 館和蒸気圧とに比例する。実在の溶剂ては複雑 な関係となるが、物理化学的性管の類似した成 分のみから成る溶剂は理想溶液に近似出来ると いわれている。そこでこのような混合溶郕から の蒸発の過程を、次のように考えて予测の可能 性を検討した。

いま、モル数 $\left(\mathrm{X}_{1}\right)$ 。の溶液と気波平衡状態 にある体積Vの気相を完全に除去してから、新 たに新鮮空気 Vを入れて新しい気液平衡を達成 させた時の溶液中の $\mathrm{i}$ 成分の)モ几数を $\left(\mathrm{X}_{\mathrm{i}}\right)_{1}$ とすると、これらのモル数の間には（1）式の 関係が成立し、各成分の分压 $\left(p_{i}\right)_{1}$ 付 (2) 式て表される。ここで $\mathrm{P}_{\mathrm{i}}$ は i 成分の飽和蒸気 压、 $\Sigma_{i}\left(X_{i}\right)_{1}$ 㤬全成分のモ儿数の和、 $\alpha=$ $\mathrm{V} /(\mathrm{RT}) \mathrm{T}$ 、Rは気体常数、Tはこの液相 の温度 $\left({ }^{\circ} \mathrm{K}\right)$ でる。この過程を順に繰り返 せ估、( $\left(X_{i}\right)_{2},\left(X_{i}\right)_{3}$..・を得ること が出来る。この仮定的な操作の前後にお讨る $\mathrm{i}$ 成分のモル数の変化を、、、の值を可能な限り小 さくし（1）式を用いた近假計算にによって求 めれば、溶滀表面における気相を一定流量で流 した場合の気相中成分灌度变化の予测が出来る と思われた。

そこて波体の重量変化を湖定し、同時に流出 する空気中の各成分量を测定して (1) 式によ る計算の結果と比較した。ベンゼンとトルエン の混合溶湾は、理想溶洨として取り扱うことか 可能てあるのて実呀試料として利用した。测定 された輀成分の気中算度と、(1) 式と（2） 式とから求めた漕度の計算值との一致はよくな かったか、ベンゼンとトルエンの気中壊度の比 の実测值之計算值とはかなりょく一致した。

$$
\begin{aligned}
&\left(\mathrm{X}_{1}\right)_{1}=\left(\mathrm{X}_{i}\right)_{0} /[1+ \\
&\left.\left\{\left(\alpha \mathrm{P}_{i}\right) / \Sigma_{1}\left(\mathrm{X}_{1}\right)_{1}\right\}\right] \\
&\left(\mathrm{p}_{1}\right)_{1}=\mathrm{P}_{i}\left(\mathrm{X}_{1}\right)_{1} / \Sigma_{1}\left(\mathrm{X}_{i}\right)_{1}
\end{aligned}
$$

尿中メタノールのヘッドスペース法による分析の検討

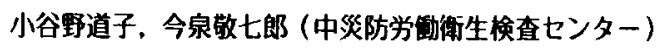

尿中メタノール搌度はメタノールおよび酰メチル暴 露の指標の一つとされている。 その分析方法として操 作が簡易で、尿中揮器性成分の定量方法として有效之考 えられていッッドスペースガスクロマトグラフ法につい て、より安定した分析值を得られる方法を検討した。

分析手順は次のようである。試料尿をスクリューバ イヤル中に一定量採取し、内部標準としてアセトニトリ

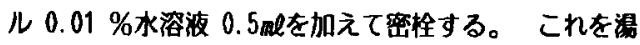
浴中で加温し、バイヤル内空気をカススイトシリンジで 畹し、一定量をガスクロマトグラフに注入して分析す る。 得られたクロマトグラムのメタノールのピークエ リアと内部標蕉のピークエリアの比を計算し、㭘量線よ り尿中メタノール湿度を求める。内部標隼として、フ タノール、プロパノール、メチルエチルケトン等を検討 し、メタノールとの分鹤状態、保持时間の長さより、こ こではアセトニトリルを用いた。 ガスクロマトグラフ は島津GC-7AG、梚出器FID、カラム充㟨郕はガスクロパ ック54、カラム温度 $85^{\circ} \mathrm{C} 、$ 注入口温度 $120^{\circ} \mathrm{C}$ で分析した。 この手順について、加温温度の朗暨を謂べるため、メ タノールを添加した試料尿 1.0 吼を7 铺バイヤル内に 採取、密栓し、 $40^{\circ} \mathrm{C} \sim 65^{\circ} \mathrm{C}$ の各温度の晹浴中で 15 分間加 温した。 メタノールのピークエリアは $40^{\circ} \mathrm{C} よ り 65^{\circ} \mathrm{Cの}$ 加温の場合、約了倍に增大した。得られたガスクロマ トグラムは、メタノールのピークにテーリングは認めら れず、分離も良好であった。加温温度が60Cで一定の とき、加温時間をかえた場合、メタノールとアセトニト リルのピークエリア比は11分から37分の間で一定であっ た。尿中メタノールの生理值は䄪 2 的 $/ \ell$ と報告され ているので、この綮度を定量するためには60兄、15分間 の加温が必要と思われた。検量線作成のときの共存物 による既䇺をしらべるため、非暴露者尿、情製水、人工 尿のそれぞれにメタノールを添加し、メタノール添加量 とピークエリア比の関係をみた。このときの加温は $60^{\circ} \mathrm{C} 、 15$ 分間とした。3本の検量線は 0 から80mg $/ \mathrm{l}$ の広い管囲にわたって良い直楾性を示しており、その㑯 きの間にも大差はみられなかった。これより精製水に メタノールを添加して作成した検量線により尿中メタノ 一ルの定量分析が可能と考えられた。そこで、この方 法により非暴露者19名の尿中メタノール灙度を分析し たところ平均值は $1.41 \mathrm{mg} / \mathrm{l}$ 、分析值の䈍囲は

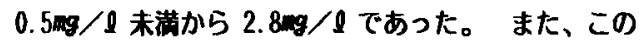
方法による添加回収事は、 $7.9 \mathrm{mg} / \ell$ 添加の場合 $100 \%$ 、 変動係数は $6.6 \%$ あった。 
212

䐂中ぬタノール*アセトンの分析方法と正常值 について

河合俊夫'平岛次郎'堀口俊一2

1. 近镜安全桷生サービスセンタ一，

2.大阪市大医懪境街生

展中ょタノールの即定方法は吸光光度法やサス

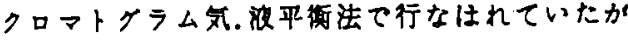
、分析感度に問題があった。度近、水溶液を直接 CC

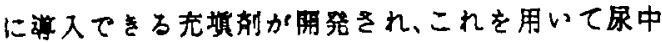
シタノールを分析する方法を見出した。方法は尿

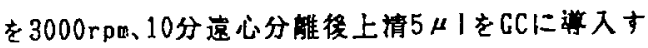
る。その結果GC気. 液平得法に比べて的5倍の感度

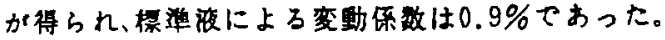
分析策件は办来イオン㛟出器、充填制はshimarlite $\operatorname{TP} \Lambda(60 \sim 80$ メシュ)液相SBS100 10\% カ 7 厶 $4 \mathrm{~m} X$

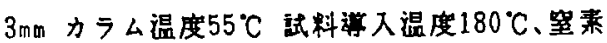
$45 \mathrm{ml} / \mathrm{min}$ 、空武 $0.5 \mathrm{Kg} / \mathrm{cm}^{2}$ 、水素0.6 $\mathrm{Kg} / \mathrm{cm}^{2}$ でおこな った。こク分析策件ではタタ/ール、アセトンの任 かイソプロピルアルコール、ベヒンとエチルアル コールおよひその代㙞であるアセトアルデヒド なとの同洔剧定が可能でる。正常值として溶绪 に堭貉されていない男子74名の平均值は尿中»タ ノール实別值 $2.06 \mathrm{mg} / 195 \%$ 上限值 $3.30 \mathrm{mB} / 1$ 尿比

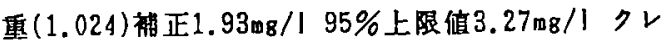
アチニン補正1.74m8/8 クレアチニン $95 \%$ 上限值 $3.52 \mathrm{mg} / \mathrm{g}$ クレ厡中アセトン実即值0.39m8/195\% 上限值 $0.93 \mathrm{mg} / 1$ 尿中比重補正 $0.37 \mathrm{mg} / 195 \%$ 上限 值 $0.88 \mathrm{mg} / 1$ クレアチニン補正0.35m8/8クレ $95 \%$ 上限值 $1.04 \mathrm{mB} / 8$ クレが得られた。タタノール取り 报い作策者に对する施用では罢境涱度が36〜 402

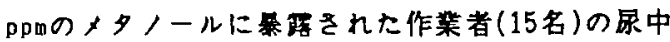

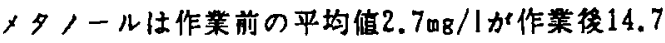
m8/ と䄪5倍の増加が見られた。
座長のまとめ（210～212）

長谷川 弘道（常枈浜松大創立事務所）

210 : 混合溶剂の種類とその使用方法がすかっている 場合、その気中涯度の推移をあらかじめ推定しようとい う試みを報告している。有機溶用を使用する工場の潵境 管理に関する重要な命題と考えられる。实呀はトルエン とベンゼンの混合系で行われたか、その得られた結果の 応用性が質問对象となった。現時点では混合溶剈の物 性、化学的性筫か似ている場合には、近似的予測可能と 以5。

211 : メタノール暴露の指橙として、尿中メタノール をへッドスベース法により定轾するに当たっての分析法 を㞦温温度、加温時間、検量線等について検討してい

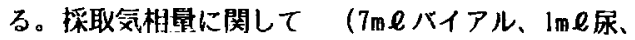
$\ln \ell$ 採取）の問があったが、やはりこの点に関する検討 が、な拟要と思すれる。

212 : 尿中メ夕ノールとアセトンの分析法として、気 液平衡法にまさる尿㨁接注入法を報告。值接拄入による インジェクター部及びカラムの污れについての対処法。 飲酒等の荿メタノール变動因子、カラム温度等について の留疑伈答があった。分析方法の簡便さ、感度等を考虑 すると意義の高い報告と考えられる。 
エタノール共存下におけるトリクロロエチレ ンの代謝——ラット灌流肝戥における実験

高野健人(東医歯大医公衛) 宮崎良文(東医歯大医衛生) 川本俊弘、芳原達也(山口大医公衛)

肝胴においてtrichloroethy lene(TCEL)はチ トクロームP-450系により、NADPHと分子状酸素 を消費し酸化されて中間代謝産物となり、主た る中間代謝産物のひとつであるchloral hydrate(CH)は、細胞内の酸化還元電位のレベル に応じてtrichloroacetic acid(TCA)または trichloroethanol(TCE)に代謝されることが知 られている。その理由はCH $\rightarrow \mathrm{TCAを}$ 促進するCH dehydrogenaseはNADを必要とし、CH $\rightarrow \mathrm{TCE}$ 促 進するalcohol dehydrogenaseはNADHを必要と するためと考えられている。一方、エタノール は細胞内のNADH/NAD比を著しく上昇させること が知られている。そこで、本報では、飲酒によ り得られる血中溽度と同等のエタノール存在下 において、細胞内酸化還元電位の変化に注目し、 TCEL代謝時のTCA, TCE生成の変化を調べた。方 法は、ラット灌流肝葴における分光分析・蛍光 分析法(詳細は日衛誌 38:649-656,1983)によっ た。TCA,TCEの测定はガスクロマトグラフによっ た。TCELを灌流湤中に加えた場合、肝臟の酸素 消費の増加、還元型PN(NADH, NADPH)の堿少、お よびチトクロームP-450スペクトル変化が観察 された。低濃度 $(50 \mu \mathrm{M}) \mathrm{TCEL}$ 負荷の場合代謝産 物は主としてTCAで、TCEは少なかったが、エ夕 ノールが共存すると、代謝産物の産生は逆転し、 TCEが多くTCAが少ないという結果が得られた。 CHを灌流液に加えた場合も、主要代謝廉物は TCAであった。この場合も、エタノール(2.0mM) の添加により息元型PNの著しい增加が認められ、 エタノール同時負荷時におけるCHの主たる代謝 産物はTCEL負荷時と同様に逆転し、TCEとなっ た。エタノール共存下におけるCH代謝時には著 明な還元型PNの消費が認められた。以上より、 エタノールの同時存在下において、TCELの代謝 は、細胞内NADHの増加により、TCEの生成が促 進するものと考えられた。

\section{トリクロロエチレンのエタノール代謝に及はすす影昌}

○䀦田 義弘 後村達也楮方 正名

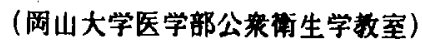

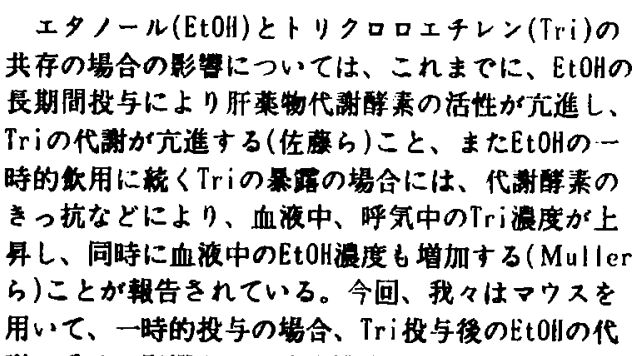

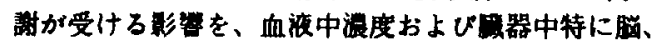
肝瀑中度の定量により梚討した。同時にEtOH投与 後のTriの代懒についても梌討した。

[方法]

マウス(キ)を用い、Tri $131 \mathrm{mg} / \mathrm{kg}$ を復璄内注射し、

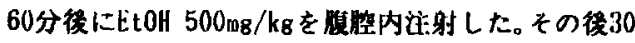
分、45分、60分に血洨、媨、肝接出し、EtOHを 定量した。また同様にEtOH投与後にfriを投与し、

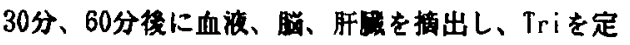
量した。すなかちバイアル形(25mI)に硫酸アンモニ

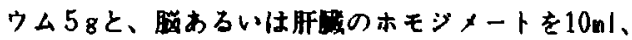

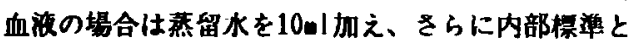
してィチルエチルケトン水洛液 $\left(29 \mu_{\mathrm{g}} / \mathrm{ml}\right)$ を $1 \mathrm{ml}$ 加

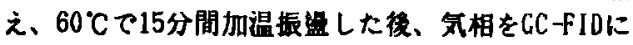
注入した。内部标隼とのビーク高比で定量した。 [耤果と考察]

Tri投与後のEtoH湿度は、血渡中、譄中において、 30分後では、コントロール(Tri非投与群)との間に 差はみられなかったが、それ以搝には減少のしかた に差(p<0.05)が㑇められるようになった。またEtOH 投与後のTri浱度も同粎の領向を示した。すなわち、 TriによりEtOHの代新が阻害され、またEtOHにより Triの代碀七阻害され、血漠中からの消失が共に荤 几る攧何にある。これは《degreasers' [| ush》のの原 因の一つとも考えられる。また隠中にも艮く湍留す

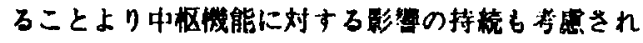

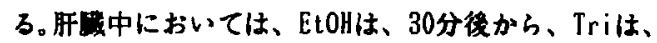
それ以後からコントロールとの間に差がみられた。 [結諭]

(1) Triをあらかじめ投与したマウスにEtOHを投

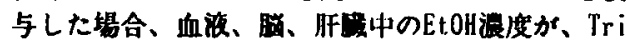
非投与群よりも高く、代辢の阻害か認的んた。 (2) EtOH投与後のTriの投与においてる、血济、

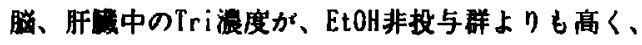
代辢の阻害が悆められた。 
トリクロロエチレンの代媩と毒性に対するアルコ

ールとフェノハルビタール投与の差異について

中島民江、冲野知轮、倉沢和成、村山忍三

（信州大医衛生）作滕章夫（山梨医大保健 1）

[目的］アルコールとフェノバルビタール (PB)によ るトリクロロエチレン(TRI) 代㙒の六進と、肝毒性 堌強作用の量一反応関係について検討した。[方 法]実験 1 : アルコール (2g/day/rat) とPB (80mg $/ \mathrm{kg}$ x4days）投与ラットに500,1000, 2000, 4000,8000pp: のTRI を 2 あるいは 8 時間暴露した。暴露終了後、 血中TRI 濃度、尿中総三塩化物 (TTC) とトリクロロ

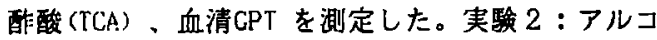
ールとPB投与ラットに2.24mol/kg のmonosodium trichloroethyl phosphate (トリクロロエタノー ル、TCE, 源として使用) とTRIを腹䶼内投与し、尿 中TTC とTCA を测定した。[結果] 1. Control と アルコール投与ラットにおけるTTC の非㳢速度はそ れぞれ500-1000ppm と1000-2000ppm付近で最大に達 していた。ところがPB投与ラットの非沬速度は 1000 -2000pp曝露後一旦ピークに達し、その後再び上㫒 した。すなわち2000ppm 以下ではアルコールの方が、 4000ppm 以上ではPBのほうがTRI 代碀の六進作用は 大きかった。2．アルコールとPBは暴露開始から24 時間に排泄されるTCA を增大させた。しかしTCAの 非汹割合 (TCA/TTC) を增大させたのはアルコールの みであった。3．アルコールとPBはTRI によるSGPT 值の上㫒を強めるが、その程度は2000 ppm 以下の暴 露港度ではアルコールの方が、4000ppm 以上の暴 露濃度ではPBの方が強かった。TTC 非汹速度とSGPT 値の間には良い相関性が認められた（2時間暴露後 は $\mathrm{r}=0.870 ， 8$ 時間暴露後は $\mathrm{r}=0.934) 。 4 . ア ル$ コールはTCE からTCA の代謝をえ進させるがPBはこ の代謝経路には影㗽を与えなかった。したがってPB 投与ラットのTCA 排泄量の增大は TRI 代謝が告進 したために相対的に增大したものと思われる。アル コール投与ラットのTCA 量の增大はTRI 代謝とTCE からTCA の代謂の六進によるものであろう。［ま とめ]アルコールとPBはTRI 代射を衣進させ、TRI の肝毒性を強める。これらの作用は2000ppm 以下の TRI 暴露においてはアルコールの方が、4000ppm 以 上のTRI 暴露においてはPBの方が強い。アルコール はTCE からTCA の代謝を高めるが、PBはこの代謝経 路には影響をおよぼさない。TRI の肝毒性はTTCの 排法速度とよい関連性をもっている。

\section{芳原達也（山口大医公整街生）}

（2１3）：トリクロロエチレン及び抱水クロラ 一ル投与時に、エタノールを添加すると、両物算 ともにトリクロロエタノールの産生が促進し、ト リクロロ䣫酸の産生が低下した。この原因は、肝

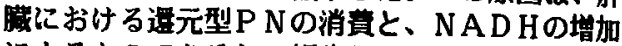
によるものであるとの報告がなされた。これに対 し、野見山（自治医大）から、動物㮔差による代 貄変化、また、佐藤（山梨医大）加ら、どうして T C Aの産生が少ないのかなど活発な筫疑応答が なされた。

（214）:エタノールとトリクロロエチレンを 同時投与すると、トリクロロエチレンの代梼が抑 制されるとの報告であった。これに対して、演題 213 の結果との関係についての䝷問がなされた。 演題 213 は肝粃だけの成嘖であり、演題 214 の成綪は whole body であるので、督、肺、腸管 等のとりくろろえちれんの代謝が加わっているの で、このような結果になったむのと推测されると の答えがあった。

（2１5）:アルコールとフェノバルビタールに よるトリクロロエチレン代梼の促進と肝毒性增強 作用の量反応関係沉ついて実馀し、2000ppm 以下 では、アルコールの方が、4000ppm 以上ではフェ ハバルビタールの方が肝毒性が強く出現し、また、 アルコールはトリクロロエタノールからトリクロ 口酢酸への代謝を促進させるとの報告がなされた。 これに対して、トリクロロエチレンの代誹に関与 する酥素について活発な筫疑応答があった。 